\title{
Effects Of Mustard Seed Oil On Prolong On Protein-Bound Iodine,Globulin And Albumin Of Albino Rats
}

\author{
Aloh Godwin Sunday ${ }^{1}$, Obeagu Emmanuel Ifeanyi ${ }^{2}$ and Okafor Arinze $\mathrm{H}^{3}$. \\ 1.Lecturer,Department of Biochemistry,Michael Okpara University of Agriculture,Umudike,Abia State,Nigeria. \\ 2.Diagnostic Laboratory Unit,University Health Services Department, Michael Okpara University of \\ Agriculture,Umudike,Abia State,Nigeria. \\ 3.Department of Biochemistry,Ebonyi State University,Abakaliki,Nigeria.
}

\begin{abstract}
The effect of commercial-grade mustard seed oil on plasma protein-bound iodine (PBI), globulin and albumin levels was studied in albino rats. Group 2 (experimental rats) was given $0.1 \mathrm{ml}$ of the oil orally three times daily for five days, while group 1 (control) was not. At the end of the five days, the mean concentrations of PBI, globulin and albumin levels in the experimental rats were $3.96 \mu \mathrm{g} / \mathrm{ml}, 0.35 \mathrm{~g} / \mathrm{dl}$ and $3.85 \mathrm{mg} / 100 \mathrm{ml}$ respectively when compared with the control values of $3.43 \mu \mathrm{g} / \mathrm{ml} .0 .35 \mathrm{~g} / \mathrm{dl}$ and $2.55 \mathrm{mg} / 100 \mathrm{ml}$ respectively. This study indicates that mustard seed oil causes the binding away of metabolic iodine that does not involve immunologic mechanisms since the globulin level did not differ from that of the control, while not impairing the transport of thyroxine to the target organs as albumin level was not lowered.
\end{abstract}

Keywords: Mustard seed oil, thyroxine, albumin and iodine.

\section{Introduction}

Mustard seed oil is from the mustard seed of mustard plant, which belongs to the scientific family Brassicaccae. Mustard plants are annual plants with weedy stem and about 2 to 6 feet high; indigenous to Himalayan Mountain, Europe, Asia, Eastern Mediterranean region and Middle East. Worldwide, there about 375 genera and 3200 species. All mustard species are edible although some taste better than the others (Hemmingway, 1995).

There are three principal types of mustard seed used to make mustard oil; black mustard (Brassica nigra), White mustard (Brassica alba), and brown mustard (Brassica juncea) (Bryan and Lower, 1996).

The term mustard oil is used for three different oils that are made from mustard seeds.

* A fatty vegetable oil resulting from pressing the seeds.

- An essential oil resulting from grinding the seeds, mixing them with water and extracting the resulting volatile oil by distillation.

- An oil made infusing mustard seed extract into another vegetable oil, such as soybean oil.

The oil makes up about $30 \%$ of the mustard seed. Mustard seed oil has about $60 \%$ monosaturated fatty acids of which $42 \%$ is erucic acid $12 \%$ oleic acid, it has $21 \%$ polyunsaturates of which $6 \%$ is omega-3 alpha-linoleic acid and 15\% omega- 6 linoleic acid and it has $12 \%$ saturated fats . In northern parts of India, mustard seed oil is used for rub downs and massages, thought to improve blood circulation, muscular development and skin texture; the oil is also antibacterial. The oil is also sometimes used prior to sexual intercourse on the male genitalia to enhance erections or strengthen virility.

The effects of erucic acid from mustard oil on human health are controversia. However, no negative effects on humans have been documented but due to the presence of this erucic acid mustard seed oil was once considered unsuitable for human consumption in the United States, Canada and the European union due to high content of this acid . Mustard oil also contains over $92 \%$ of allyl isothiocyanate. Allyl isothiocyanate is toxic and irritates the skin and mucous membranes (Darmstadt, et al., 2002).

\section{AIMS AND OBJECTIVES.}

Mustard seed oil has been reported to have some medicinal/ pharmacological properties and also some toxic and harmful effects on humans.

Here, this project was undertaken to achieve the following objectives.

* To ascertain the effects the mustard oil has on the protein-bound iodine

* To also evaluate the effects the mustard oil has on the albumin and globin levels.

\section{MATERIALS}

II. Materials And Methods

\section{TEST SAMPLES}

Six (6) albino rats obtained from the University of Nigeria, Nsukka. 
Mustard oil (200ml) obtained from St. Theresa's Catholic Church, Nsukka.

\section{METHODS}

\section{SAMPLE PREPARATION}

The albino rats used for the study were divided into two groups, control group which consists of two (2) albino rats and the test group which consists of four (4) albino rats. The body weighing balance to determine the amount of mustard oil to be administered per animal.

$1 \mathrm{ml}$ of oil

Where b.wt is the body weight of animal $1000 \mathrm{~g}$ bodyweight (b.wt)

The mustard oil was administered to the animal twice a day.

\section{DETERMINATION OF PROTEIN-BOUND IODINE CONCENTRATION}

To $0.5 \mathrm{mls}$ of serum, $3.5 \mathrm{ml}$ of distilled water and $0.5 \mathrm{ml}$ of $10 \%$ Zinc sulphate was added and mixed with a glass rod. $0.5 \mathrm{ml}$ of $0.5 \mathrm{~N} \mathrm{NaOH}$ was added and mixed well and allowed to stand for 15 minutes. The mixture was centrifuged at 3000rpm for 10 minutes and the supernatant decanted off gradually $0.5 \mathrm{ml}$ of distilled water was added to the residue and stirred with a glass rod mildly. The mixture was centrifuged again for 10 minutes at 3000rpm and the supernatant decanted off. Wash two more times. $0.5 \mathrm{ml}$ of $2 \mathrm{~N} \mathrm{KOH}$ was added and stirred with a glass rod. The residue was washed with $0.5 \mathrm{ml} \mathrm{of} \mathrm{H}_{2} \mathrm{O}$ which was added drop by drop down the rod and decanted off. The residue was digested with $2 \mathrm{ml} \mathrm{H}_{2} \mathrm{SO}_{4}$ and $5 \mathrm{ml}$ of nitric acid. Make up to $10 \mathrm{ml}$ with distilled $\mathrm{H}_{2} \mathrm{O} .2 \mathrm{ml}$ of the digested residue was put into the test tube and $0.25 \mathrm{ml}$ of $0.1 \mathrm{M}$ arsenite solution i.e. 1:2 dilution of $0.5 \mathrm{ml} \mathrm{H}_{2} \mathrm{SO}_{4}$ hydrochloric acid and stood for 10 minutes. After 1 minute interval $0.5 \mathrm{ml}$ of ceric ammonium sulphate was added into each of the test tubes and mixed. Take the reading at $420 \mathrm{~nm}$ against a reagent blank within 15 minutes.

\section{DETERMINATION OF ALBUMIN CONCENTRATION}

$0.2 \mathrm{ml}$ of the serum was put into a centrifuge tube. $0.1 \mathrm{ml}$ of acetate buffer was added and stirred. $0.7 \mathrm{ml}$ of cold methanol was added and stirred and the mixture was put in the fridge where it stood for 30 minutes at $0^{\circ} \mathrm{C}$. It was then centrifuged at $3000 \mathrm{rpm}$. The filtrate was collected and absorbance was taken at $470 \mathrm{~nm}$ against a blank to determine protein.

\section{DETERMINATION OF GLOBULIN CONCENTRATION}

$0.1 \mathrm{~g}$ of the sample was transferred into a kjedahl flask and $2 \mathrm{ml}$ of digestion mixture (sulphuric acid + potassium sulphate and a catalyst usually copper) was added. It was heated until clear, it was made up to $20 \mathrm{ml}$ with distilled water. $2 \mathrm{ml}$ was transferred into 3 test tubes and $0.5 \mathrm{ml}$ of Nesslers reagent was added, mixed and $1 \mathrm{ml}$ of $0.1 \%$ gum ghatti was added. The solution was added up to $10 \mathrm{ml}$ with water and absorbance taken at $490 \mathrm{~nm}$ against a blank.

\section{Results}

Results of Protein-Bound Iodine, Albumin and Globulin in serum of test samples. Table 4.1: concentration of serum protein-bound iodine

\begin{tabular}{ll} 
TEST SAMPLES & CON \\
\hline Group 1 & 3.07 \\
Group 2 & 4.04 \\
Group 2 & 3.86 \\
Group 2 & 4.94 \\
Group 1 & 3.78 \\
Group 2 & 3.01 \\
\hline
\end{tabular}

\begin{tabular}{|c|c|c|}
\hline TEST SAMPLES & Table 4.2: & $\begin{array}{r}\text { Concentration of serum globulin } \\
\text { CONCENTRATION }(\mu \mathrm{G} / \mathrm{ML})\end{array}$ \\
\hline Group 1 & & 3.05 \\
\hline Group 2 & & 0.37 \\
\hline Group 2 & & 0.25 \\
\hline Group 2 & & 0.33 \\
\hline Group 1 & & 0.35 \\
\hline Group 2 & & 0.46 \\
\hline
\end{tabular}


Table 4.3: Concentration of serum Albumin

\begin{tabular}{ll} 
TEST SAMPLES & CONCENTRATION $(\boldsymbol{\mu G} / \mathbf{M L})$ \\
\hline Group 1 & 2.65 \\
Group 2 & 5.58 \\
Group 2 & 4.03 \\
Group 2 & 3.47 \\
Group 1 & 2.45 \\
Group 2 & 2.31 \\
\hline
\end{tabular}

Note: Group 1 is the control where the group 2 is the test subjects.

\section{Discussion}

In this study, the effect of commercial-grade mustard seed oil on protein-bound iodine (PBI), Globulin and albumin levels of six (6) albino rats. The rats were divided into two groups; Group 2 (experimental rats) and group 1 (control). The means of the results of the results of the concentration of the protein-bound iodine, globulin and albumin of the albino rats.

The mean of the concentrations of PBI, globulin and albumin of the experimental rats from the results of the concentration of PBI, globulin and albumin in section 4.1 ; tables $4.1,4.2$ and 4.3 are $3.96 \mu \mathrm{g} / \mathrm{ml}, 0.35 \mathrm{~g} / \mathrm{dl}$ and $3.85 \mathrm{mg} / 100 \mathrm{ml}$ respectively while the mean of the concentrations of PBI, globulin and albumin of the control rats from the results of their concentrations were $3.45 \mu \mathrm{g} / \mathrm{ml}, 0.35 \mathrm{~g} / \mathrm{dl}$ and $2.55 \mathrm{mg} / 100 \mathrm{ml}$ respectively.

These results shows increase in the levels of protein-bound iodine and albumin and no change in the level of globulin. From the results, it can be drawn that mustard seed oil caused the binding away of metabolic iodine and this does not involve the immunologic mechanisms since the mean of globulin level of the experimental rats did not differ from that of the control. The increase in the mean concentration of albumin in the experimental rats shows that mustard seed oil increased the level of albumin in the blood and van lead to a condition known as hyperalbuminemia and does not impair the transport of the thyroxine to the target organ.

\section{Conclusion}

This study indicated that mustard seed oil has effects on protein-bound iodine and albumin and no effect on globulin level of an albino rat. Iodine is a precursor of thyroxine protein-bound iodine) and deficiency in it leads to the development of goitre (a disease of the thyroid gland). Goitre affects mostly people from South America, Asia and Africa. Because they are over consume plant of the Brassicaceae family. The study also shows an increase in the level of albumin which serves as a major transport media and an increase in the level of albumin over the normal range to a condition known as hyperalbuminemia.

\section{References}

[1]. Bryan, J. and Lower, H. (1996). Lloyd's Survey Handbook, 6, Aufi., London, New York, Hong Kong, 6.

[2]. Darmstadt, G. L., Mao-Qiang, M., Chi, E., Saha, S. K., Ziboh, V.A., Black, R. E., Santosham, M., and Elias, P. M. (2002). Impact of oil on the skin barrier: possible implicatons for neonatal health in developing countries. Acta Pediatrics, 91 (5): $540-554$.

[3]. Hemmingway, J. S. (1995). The utilization of mustards. A Journal of Economic of Botany, 13: (3), $196-204$. 